\title{
I Want It, Too: A Correlational Study on the Link Between Youth Celebrity Idolization and Materialism
}

\author{
Alanna Zhang ${ }^{1}$ and Jamie Kennedy ${ }^{1}$ \\ ${ }^{1}$ Chadwick School, Palos Verdes Peninsula, CA, USA
}

\section{$\underline{\text { ABSTRACT }}$}

As developments in digital technology, production strategies, and advertising techniques have skyrocketed, the current decade has often been coined the Fourth Industrial Revolution. Throughout the 1900s, flurries of social psychologists assessed the impact of the rise of television, thus producing much of the existing research relating media to materialism (Richins, 1987; Schwab, 2016; Wu, 1998). Similarly, however, online social media usage among youth has been on the rise, and concerns about its impact have accompanied it (O'Keeffe \& Clarke-Pearson, 2011; Rideout, 2018). The United States is experiencing record-high rates of adolescent depression and suicide (Curtin, 2019; Geiger \& Davis, 2019), impelling parents and scholars alike to weigh the potential negative and positive effects of social media's permeation in teens' lives (Best et al., 2014; Weinstein, 2018).

\section{Gap in Research}

Upon reviewing the existing literature, it appears that a multitude of studies detail the negative internal and interpersonal effects of materialism, and others assert that advertising viewing is positively correlated with materialism. However, few studies directly focus on advertisements with celebrity product endorsement in particular. Moreover, no studies have directly tested the relationship between celebrity product advertising and materialism in the young adolescent (ages 11-14) demographic. Given the recent surge in this type of marketing on online social media (Burke, 2019), future research should examine trends there rather than in television and print, which are mediums that researchers have focused on in the past but are now losing popularity among youth (Katsingris, 2019). Much of the existing research of celebrity influence on youth deals with the common antecedents to idolization (North et al., 2007) and even negative behavioral outcomes (Hoffman et al., 2017; Phua et al., 2017), but does not test its relation to materialism.

This study will attempt to bridge these various gaps through the following research question: In 2020, how does the viewing of Instagram celebrity product endorsement correspond with levels of materialism (with a focus on its relationship to well-being and generosity) in middle schoolers in Southern California?

\section{Materialism}

\section{Historical Origins}

The concept of materialism originated in seventeenth-century philosophy when Ralph Cudworth used the term "materialism" to describe theories about the composition of the universe (Steinfield, 2016). During the nineteenth century, however, the Industrial Revolution spurred concerns that the widespread availability of goods and their increasing significance in society could be problematic (Bakırtaş et al., 2014). Thus, materialism evolved out of philosophical definitions and landed in the common vocabulary, especially among the upper class, to refer to individuals who prioritize the possession of goods over social and spiritual goals (Oxford English Dictionary, 2016). Researchers distin- 
guish materialistic individuals in their use of material acquisition to pursue happiness rather than through "relationships, experiences, or achievements" (Richins \& Dawsons, 1992). Not all material pursuits are detrimental and are often important to having a natural, enjoyable, and healthy lifestyle (Rucker \& Galinskey, 2009; Srivastava et al., 2001). Although some researchers do point out the positives of materialism such as motivation and belonging (Rucker \& Galinskey, 2009; Srivastava et al., 2001), the research reviewed overwhelmingly denotes a correlation between increased levels of materialism and undesirable outcomes. When the acquisition of goods takes precedence over other methods of achieving happiness, it begins to harm the individual and society.

\section{Internal Manifestations}

There is considerable research on the potential negative effects of materialism on a person's well-being. Primarily, a substantial body of research reveals the negative correlation between materialism and life satisfaction (Ahuvia \& Wong, 2002; Burroughs \& Rindfleisch, 2002; Keng, 2000; Shrum et al., 2011; Sirgy et al., 2012). According to psychologist Jo-Ann Tsang, a focus on acquiring more goods tends to cause greater levels of material dissatisfaction, which then spills into a general life dissatisfaction (2014). A review of the research also illustrates that materialism is both a frequent antecedent and corollary of psychological troubles such as self-criticism (Wachtel \& Blatt, 1990), anxiety and stress (Burroughs \& Rindfleisch, 2002), and depression (Yamaguchi \& Halberstadt, 2012). People who endorse materialistic principles even report a greater number of unpleasant emotions and physical symptoms such as headaches and stomachaches (Kasser, 2014). Accordingly, materialistic individuals rely on spending to cope with underlying psychological needs rather than addressing them appropriately. Over time, material goals may go as far as to come at the expense of more sustainable pursuits in life if a person sacrifices more noble goals to simply acquire wealth and shop, potentially creating a vicious cycle of unfulfillment.

\section{Social Consequences}

In addition, individual materialism may have negative effects on one's interpersonal behavior. In fact, social psychology authors Bredemier and Toby contend that materialistic culture is the root of many social ills (1960). Richins and Dawsons found that those holding more materialistic beliefs were less willing to share their money, whether it was to charity or simply to friends and family (Muncy \& Eastman, 1998). Thus, the significance materialism places on goods not only translates to personal detriment but also decreases one's generosity toward others. Materialistic individuals often compare their wealth relative to others', which has the danger of developing into a "disinclination to trust other people and engage with them in deep, collaborative ways," (Bauer et al., 2012) suggesting a link between materialism and decreased social involvement overall, which is problematic since socializing is a tenet of sustainable well-being. Therefore, because materialism is associated with decreased generosity and self-reported quality of life, it raises serious concerns about the ramifications caused by systems that promote it.

\section{Advertising and Materialism}

While psychological factors play a role, external factors have a significant impact on individuals' development of materialism. In emphasizing the importance of material goods, advertising connects the marketed possessions to an improved state of happiness (Opree et al., 2012), promoting the central idea of materialism. Consumer researchers embed persuasive appeals into advertisements to depict the products as essential in the modern-day and curative of life problems (Lee \& Shrum, 2012). A substantial body of research shows the more frequently adults view television advertising, the more positively they view wealth and luxury objects (O'Guinn \& Shrum, 1997; Opree et al., 2013). This relationship between advertising and television viewers' attitudes may very likely be playing out in today's social media landscape as well. 


\section{Trends in Middle School}

Previous research also speculates the vulnerability of young people-particularly adolescents aged 11-14-to the effect of advertising on materialism, prompting special attention to the corresponding middle-school demographic in particular. Chaplin and John concluded that materialism peaks during the 7th and 8th grade age group because it is "a time when individuals learn to think abstractly about themselves and about their world" and "when they experience a major dip in self-esteem" and may use material belongings to cope with feelings of deflated self-worth (2005). Studies explain that the newly competitive social dynamics of middle school reinforce materialistic messaging in advertising (Pinsker, 2018) which is troubling considering that middle schoolers feel less secure in themselves. In fact, a survey by Harris Interactive found the majority of American pre-teens agreeing with the sentence, "I would be happier if I had more money to buy more things for myself" (Reuters, 2007). When a similar study compared middle school students to people of other age groups directly, the middle schoolers gave the most material-oriented responses to what makes them happy, citing "money" and "brand names," rather than "being with friends" or "no homework" (Chaplin \& John, 2007). Today, however, the unsympathetic middle-school environment is not the only factor influencing materialism in young teens.

\section{The Prevalence of Advertising for Young Social Media Users}

In recent years, social networking sites have adopted a central role in the lives of young people, enabling wide opportunities for advertisement toward this audience. According to Publicis Media, global advertising expenditures on social media will rise $20 \%$ in 2019 to $\$ 84$ billion, surpassing print advertising for the first time. The growth is expected to further accelerate, as it should nearly double by the year 2023 (Zenith Media, 2019). Not only are social media advertisements becoming more prevalent, but more children are also using such sites: social networks require users be at least thirteen years old, yet the average individual nowadays owns a smartphone at 10 years old and opens a social media account at 11 years old (Influence Central, 2017). Furthermore, the prevalence of advertising seems to have a strong effect on users. In a recent international retail survey, it was found that purchases of the majority of consumers worldwide are inspired by social media (Maxwell, 2017), and in the United States, $76 \%$ of consumers have purchased a product after viewing it on a social media post (Curalate Inc., 2017).

\section{The Influence of Media Celebrities During Early Adolescence}

In the years leading up to and throughout the teenage years, young people formulate their own identities, which may include comparing themselves to peers, questioning parents, and finding new influences (Wolfe, 2016). Adherents to the theory of the so-called generalized social comparison state that an individual may gauge their social status by comparing their material possessions to those of others (Saunders, 2001). In addition to comparison among their peers, adolescents also compare themselves to media celebrities. For these reasons celebrity idolization is common among youth universally (Yue \& Cheung, 2000; Tiller, 2011).

Research has gone so far as to demonstrate that celebrities have a large influence on viewers' beliefs and behavior (Schultze et al., 1991; Schouten et al., 2019). Young people imitate celebrities in many ways; in an ethnographic analysis, Caughey discovered that young consumers view admired celebrities as ideal images of themselves, hoping to gain similar characteristics. The admirers reported a desire to refine their personalities, appearance, and abilities (1994). Thus, many young people idolize public figures who seem especially attractive (Sansone \& Sansone, 2014), wealthy (evidenced through visuals of their expensive lifestyles), and happy. However, celebrities differ from other individuals in that they are most often curated by media through high levels of editing, glamorous clothing, cosmetics, and publicity training (Nouri, 2018) while simultaneously attempting to showcase "ordinary, approachable, and authentic personalities" (Chapple \& Cownie, 2017). Therefore, young adolescents on social media may be misled since they are unfortunately both less aware of the media's unrealistic depiction of celebrities and more vulnerable to idolizing them nonetheless. Further, interactive features on social media such as commenting and liking leads to a virtual relatability with the celebrity (Scmidt, 2007). Along this vein, a survey of 75 individuals between the ages of 17 and 35 found that those who felt a connection to their idols were more likely to report that their idols-all media 
celebrities-factored into their own self-esteems, work ethic, and ideas about morality (Boon, 2001). While these findings certainly demonstrate that celebrity influence plays a notable role in an individual's beliefs and values, no studies focused on materialistic beliefs and values.

\section{The Effectiveness of Celebrity Endorsement}

Existing consumer research has indicated that young consumers are often more likely to make purchases when the products are endorsed by famous artists, entertainers, and athletes (Lafferty \& Goldsmith, 1999; Elberse et al., 2011). Today, half of consumers in the United States say that they feel more inclined to buy products from images or videos on social media when the media includes testimony from real, satisfied buyers, which is heightened when the testimony comes from a public figure (Curalate Inc., 2017). Therefore it may not come as a surprise that empirical data have established that celebrity influence increases the purchase intentions of adolescents (Martin \& Bush, 2000) and overall advertising effectiveness (Bergkvist \& Zhou 2016). Marketers are very much aware of the efficacy of celebrity product endorsement and have capitalized on such opportunities; a study by Harvard Business School found that obtaining a major endorser increases the company's revenue by up to $\$ 10$ million each year and yields an increase in stock returns (Elberse \& Verleun, 2011). For instance, in 2004, the sales of luxury company Chanel increased 30\% when actress Nicole Kidman was paid to endorse the company's perfume in a 30-second television commercial (Creswell, 2008).

\section{Methodology}

\section{Choice of Instagram}

A striking $92 \%$ of marketers choose Instagram as their first choice for endorsements, and $60 \%$ of media figures also consider Instagram the most important platform in engaging with followers (Linqia, Inc., 2016). Moreover, a recent case study on 593 students in the United States found that the most popular network among middle schoolers, by far, was again Instagram (Martin et al., 2018). There, up to one out of every four posts the average user views daily is an ad (Gesenhues, 2019), highlighting that advertising occupies a significant portion of Instagram usage. Therefore, this study will focus on the growing market of celebrity product endorsement on Instagram because it is the most popular social network among middle schoolers, marketers, and influencers.

\section{Population}

The participatory school was a coeducational independent school in Southern California. The school was a strong choice due to it being ethnically diverse and serving 46 zip codes.

\section{Sample Selection}

The survey involved only members of the 7th and 8th grade because their age range falls in the targeted "young teen" demographic. Since they are all under the age of 18, parents were emailed a consent form, and 40 out of 74 students with parental consent took part in this study. $40 \%$ were in the seventh grade and $60 \%$ were in the eighth grade, and the students resided in 8 cities. To ensure the safety of participants, an institutional review board approved the survey. 


\section{Alignment}

A cross-sectional survey was administered to participants through Google Forms to collect primary data. To investigate correlates of materialism, researchers prefer surveys because questions can be scaled, recharacterized, and contextualized (Lipovčan, 2015). Furthermore, researchers typically measure materialism, generosity, and well-being at specific points in time because they can fluctuate depending on stimuli (Chaplin \& John, 2007).

\section{Instruments}

Specifically, the questions assessed (1) generosity, (2) consumer activity, (3) celebrity idolization, (4) materialism, (5) well-being, and estimated daily Instagram usage. Organizationally, the survey, which required approximately 10 minutes to complete, contained a total of 31 questions and was divided into 4 main sections (Appendix A). Demographic information concerning grade, age, gender, and city of residence were collected first to anticipate any outstanding correlations. Subsequent sections were a preliminary questionnaire, a display of 14 images, a post-image questionnaire in which participants again answered the materialism and psychological well-being questions, and the final measurement of generosity by which they could change their donation amount (Table 1). Students were asked to rate applicable statements based on a four-point Likert scale to limit neutral responses.

1. The generosity measurement was adapted from a technique used by Chaplin (2018): participants were informed after the demographics subsection that they could receive a cash reward up to $\$ 5$ with the option of donating none, a portion, or all of the money to charity. The word "charity" was selected in order to indicate that the money would be benefiting those in need. The $\$ 5$ amount allowed for the behavioral measurement of generosity akin to a 5-point Likert scale.

2. In addition to a materialism scale, the level of care in spending habits was assessed for a more nuanced understanding of participant's level of materialism. This subsection was retrieved from the study "Effects of exposure on attitudes towards stem interests" (Kurz, 2015). Perceptions were recorded with a four-point Likert-scale from "never" to "very frequently" to two questions.

3. The survey measured the extent of celebrity worship by asking participants to rate statements, "I want to be as smart as movie idols, I want to be as trendy as models on social media," and "I aspire to the lifestyles of celebrities." These align with Kasser's notion of "exposure to materialistic models" (Kasser, 2004).

4. Materialism was measured using the Youth Materialism Scale (YMS), a scale used in over 485 studies (Goldberg et al., 2003). Five out of eighteen questions were selected to keep the survey at a reasonable length for the middle schoolers because survey fatigue results in unreliable responses (Porter, 2004).

5. Well-being was assessed through the lens of the Satisfaction With Life Scale to measure the difference (if any) between participants' life satisfaction before and after the Instagram advertisements (Pavot \& Diener, 2008). The scale's credibility is attributed to it being used by past researchers over 26,000 times (Diener, 2010).

6. Fourteen photos were selected of popular media celebrities (Table 1, Row 8). For example, the two models selected, Kylie Jenner and Gigi Hadid, were ranked by Vogue Magazine in 2019 as two of the most followed supermodels on Instagram; meanwhile, basketball player Lebron James was selected not because of the number of Instagram followers but for his widely-accepted fame among youth (Salessy, 2019). Of course, the celebrity selection was limited to those who had partnered with companies on Instagram in the past.

\section{Implementation Details}

A third-party assistant emailed the survey to each participant since emailed surveys produce higher response rates (Fincham, 2008). Students were reminded upon beginning the survey that they could opt-out at any time. Furthermore, 
students were permitted to take the questionnaire on their personal computers at any time convenient to them in a three-week period because a lack of response within a sample leads to biased data (Miller). Each participant was assigned an identification number. The assistant kept track of which participant corresponded with each ID number. Within the survey's demographic section, one question asked participants only for their ID number. Due to the assistant's role, IDs could not be traced to names. The researcher then matched up the cash amounts to IDs, and the assistant then matched up the IDs to actual names and delivered the reward-enclosed envelopes to the participants. These measures were employed to ensure the anonymity of data since anonymity promotes higher data quality (Murdoch et. al, 2007) and also to ensure full confidentiality of data.

Table 1: Instruments

\begin{tabular}{|c|c|c|}
\hline Questions & Measurement Scale & Source \\
\hline Demographics & Assorted & \\
\hline What grade are you in? & 7th, 8th & Self-defined \\
\hline What grade did you start at [school name]? & $\begin{array}{l}\text { Kindergarten, 1st, 2nd, 3rd, 4th, } \\
5 \text { th, 6th, 7th, 8th }\end{array}$ & Self-defined \\
\hline How old are you? & $12,13,14$ & Self-defined \\
\hline What is your gender? & $\begin{array}{l}\text { Female, male, other/prefer not to } \\
\text { say }\end{array}$ & Self-defined \\
\hline What city do you live in? & Open response & Self-defined \\
\hline $\begin{array}{l}\text { What is the ID number you were given in the email? } \\
\text { (This number allows us to give each participant the } \\
\text { cash reward afterward and will not in any way be used } \\
\text { to trace your responses back to you.) }\end{array}$ & Open response & Self-defined \\
\hline Initial Generosity & Likert Scale (1-5) & \\
\hline $\begin{array}{l}\text { Before you begin the survey, please know that you will } \\
\text { receive a } \$ 5 \text { reward after the survey is completed! Feel } \\
\text { free to keep the five dollars. If you would instead like } \\
\text { us to donate it to charity, select an amount. }\end{array}$ & $\$ 1, \$ 2, \$ 3, \$ 4, \$ 5$ & $\begin{array}{l}\text { Chaplin \& Rind- } \\
\text { fleisch }\end{array}$ \\
\hline Spending Habits & Likert Scale (1-4) & \\
\hline $\begin{array}{l}\text { I compare prices and brands before buying something } \\
\text { that costs a lot of money. }\end{array}$ & $\begin{array}{l}\text { Never (1), Rarely (2), Frequently } \\
\text { (3), Very frequently (4) }\end{array}$ & Moschis \& Moore \\
\hline I plan how to spend my money. & $\begin{array}{l}\text { Never (1), Rarely (2), Frequently } \\
\text { (3), Very frequently (4) }\end{array}$ & \\
\hline Celebrity Idolization & Likert Scale (1-4) & \\
\hline I want to be like movie idols. & Never (1), Rarely (2), Frequently & Kasser et al. \\
\hline
\end{tabular}




\begin{tabular}{|c|c|c|}
\hline & (3), Very frequently (4) & \\
\hline I want to be as trendy as models on social media. & $\begin{array}{l}\text { Never (1), Rarely (2), Frequently } \\
\text { (3), Very frequently (4) }\end{array}$ & \\
\hline I aspire to the lifestyles of celebrities. & $\begin{array}{l}\text { Never (1), Rarely (2), Frequently } \\
\text { (3), Very frequently (4) }\end{array}$ & \\
\hline Instagram Usage & Assorted & \\
\hline Do you have an Instagram account? & Yes, No & Self-defined \\
\hline $\begin{array}{l}\text { If you answered yes to the previous question, how long } \\
\text { do you spend on Instagram on a typical day? (estimated } \\
\text { time spent) }\end{array}$ & Open response & Self-defined \\
\hline Initial YMS & Likert Scale (1-4) & \\
\hline $\begin{array}{l}\text { I would be happier If I had more money to buy more } \\
\text { things for myself. }\end{array}$ & $\begin{array}{l}\text { Never (1), Rarely (2), Frequently } \\
\text { (3), Very frequently (4) }\end{array}$ & Goldberg et al. \\
\hline I really enjoy going shopping. & $\begin{array}{l}\text { Never (1), Rarely (2), Frequently } \\
\text { (3), Very frequently (4) }\end{array}$ & \\
\hline I like to buy things my friends have. & $\begin{array}{l}\text { Never (1), Rarely (2), Frequently } \\
\text { (3), Very frequently (4) }\end{array}$ & \\
\hline $\begin{array}{l}\text { When you grow up, the more money you have, the hap- } \\
\text { pier you are. }\end{array}$ & $\begin{array}{l}\text { Never (1), Rarely (2), Frequently } \\
\text { (3), Very frequently (4) }\end{array}$ & \\
\hline $\begin{array}{l}\text { I would love to be able to buy things that cost lots of } \\
\text { money. }\end{array}$ & $\begin{array}{l}\text { Never (1), Rarely (2), Frequently } \\
\text { (3), Very frequently (4) }\end{array}$ & \\
\hline Initial Life Satisfaction & Likert Scale (1-4) & \\
\hline In most ways my life is close to ideal. & $\begin{array}{l}\text { Never (1), Rarely (2), Frequently } \\
\text { (3), Very frequently (4) }\end{array}$ & \\
\hline The conditions of my life are excellent. & $\begin{array}{l}\text { Never (1), Rarely (2), Frequently } \\
\text { (3), Very frequently (4) }\end{array}$ & \\
\hline I am satisfied with my life. & $\begin{array}{l}\text { Never (1), Rarely (2), Frequently } \\
\text { (3), Very frequently (4) }\end{array}$ & \\
\hline Celebrity-Endorsed Advertising & (presented in a scrolling view) & \\
\hline
\end{tabular}




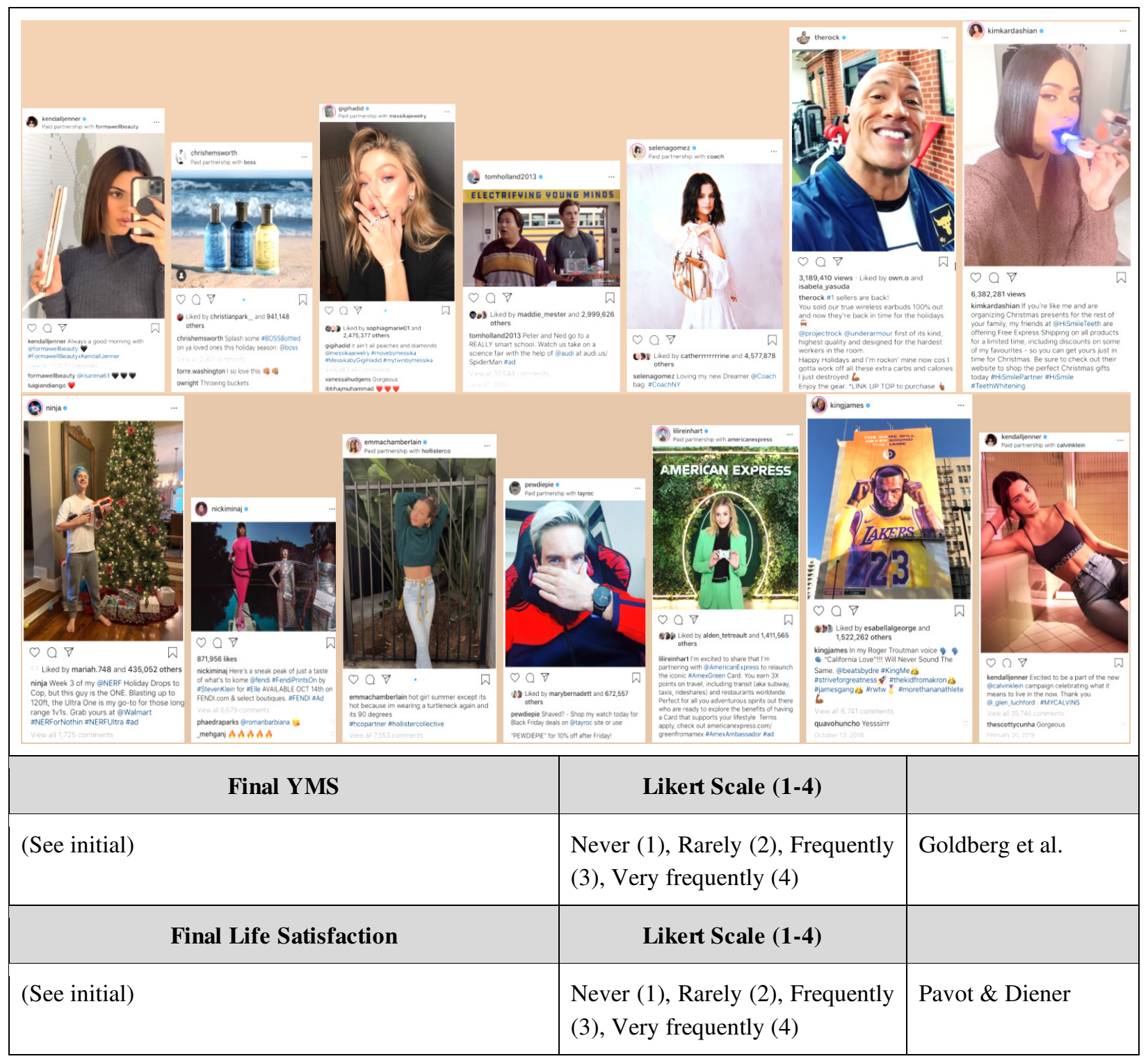

\section{Data Analysis}

Data in a Google spreadsheet were coded to their respective numerical values: $1=$ never, $2=$ rarely, $3=$ frequently, 4 $=$ very frequently. Similar to past studies, the values were averaged for general mean scores and subpopulation mean scores (Keng, 2000). Linear regression analysis was employed to compare bivariate correlations for associations in the nine aforementioned categories and the strength of correlations was determined by calculating Pearson correlation coefficients (R) (Oladipo, 2013). These strategies allowed for the measurement of baseline levels of materialism, wellbeing, and life satisfaction with an equal focus on "final" values, or those responses collected upon viewing the celebrity endorsements. 


\section{Discussion}

\section{Baseline Findings}

Among the 40 middle schoolers, the mean materialism value before viewing the images was 2.395 out of 4 (Table 2 , Column 2). These middle schoolers exhibited moderate levels of materialism since the materialism score falls midrange. Accordingly, while $67.5 \%$ agreed or strongly agreed to the statement, "I really enjoy going shopping," only $42.5 \%$ agreed or strongly agreed to the statement, "I would be happier if I had more money to buy more things for myself" (Figure 1-2). These ratings demonstrate that although the participants do enjoy shopping for material goods, they scored neutrally on the materialism scale because they did not believe they necessarily "would be happier" with more of those goods. In accordance with moderate levels of materialism, respondents had low average levels of celebrity idolization (1.80), careful average spending habits (3.13), high initial average life satisfaction (3.28), and high average initial generosity values (4) (Table 2). For context, all Likert-scale mean values scale from 1 to 4 , except generosity which scales from 1 to 5 .

Most notably, the high level of life satisfaction in combination with the moderate level of materialism is consistent with the existing body of research on the correlation between increased materialism and decreased life satisfaction in adults (Ahuvia \& Wong, 2002, Belk, 1985, Burroughs \& Rindfleisch, 2002; Shrum et al., 2011; Sirgy et al., 2012), suggesting such a phenomenon likely occurs in young adolescents as well. In addition, these findings support Belk's notion that materialism correlates with a "disinclination to give or share possessions" (Belk, 1985) since the opposite was true: arguably low levels of materialism appear in conjunction with high generosity. The respondents' reported relatively careful spending habits imply such generosity is not likely caused by merely reckless spending habits, but rather personal beliefs and values surrounding morality and generosity. Therefore, future research-in addition to measuring surveyees' spending habits-could investigate how materialism and generosity vary with different spiritual and ethical beliefs.

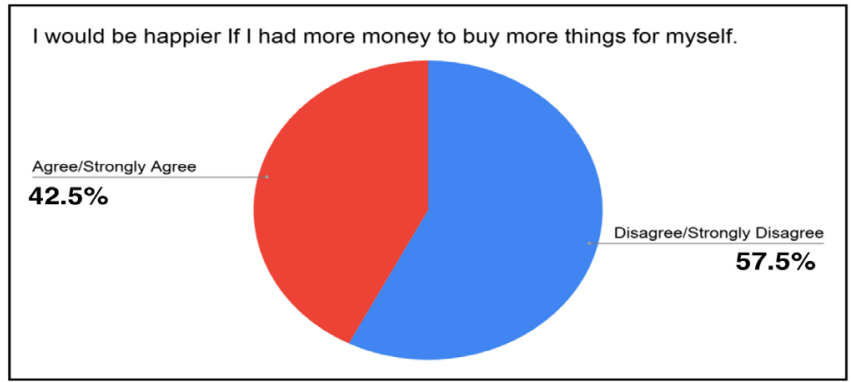

Figure 1: YMS Question 1

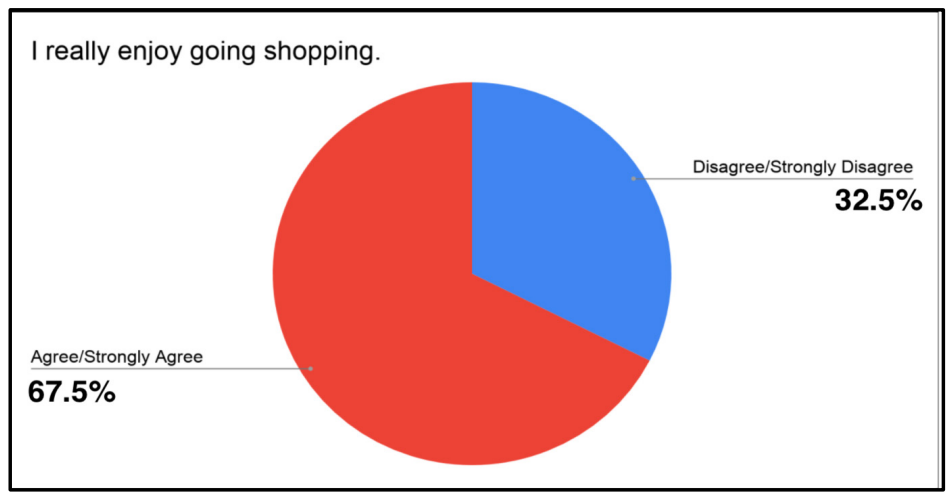

Figure 2: YMS Question 2 
Table 2: Average Values Before Viewing the Celebrity Endorsement Images

\begin{tabular}{|c|c|c|c|c|c|c|}
\hline Average Baseline Measurements & Overall & Age 12 & Age 13 & Age 14 & Girls & Boys \\
\hline Life satisfaction & 3.28 & 2.91 & 3.34 & 3.56 & 3.33 & 3.18 \\
\hline Care in spending habits & 3.13 & 3.32 & 2.89 & 3.05 & 3.06 & 2.38 \\
\hline Celebrity idolization & 1.80 & 1.62 & 1.51 & 1.89 & 1.81 & 1.75 \\
\hline Generosity before images & $\$ 4$ & $\$ 4$ & $\$ 4$ & $\$ 3$ & $\$ 4$ & $\$ 2$ \\
\hline Materialism before images & 2.40 & 2.29 & 2.41 & 2.50 & 2.23 & 2.25 \\
\hline
\end{tabular}

Table 3: Comparing Instagram Users to Non-users

\begin{tabular}{|c|c|c|c|}
\hline Averages & $\begin{array}{c}\text { Overall } \\
(\mathbf{n = 4 0})\end{array}$ & $\begin{array}{c}\text { Instagram users } \\
(\mathbf{n = 2 1})\end{array}$ & $\begin{array}{c}\text { non-Instagram users } \\
(\mathbf{n = 1 8})\end{array}$ \\
\hline Time spent on Instagram (min/day) & 22.41 & 40.75 & $\mathrm{n} / \mathrm{a}$ \\
\hline Materialism before images & 2.40 & 2.54 & 2.21 \\
\hline Celebrity idolization & 1.80 & 1.81 & 1.79 \\
\hline Care in spending habits & 3.13 & 3.16 & 3.09 \\
\hline Generosity before images & $\$ 4$ & $\$ 3$ & $\$ 4$ \\
\hline Generosity after images & $\$ 3$ & $\$ 3$ & $\$ 4$ \\
\hline Materialism after images & 2.37 & 2.50 & 2.20 \\
\hline Life satisfaction before images & 3.28 & 3.41 & 3.11 \\
\hline Life satisfaction after images & 3.40 & 3.36 & 3.44 \\
\hline
\end{tabular}

\section{Subpopulations}

In addition, the population of 40 middle school students was analyzed along the lines of gender, extent of Instagram usage, and age in order to further delve into the gap in knowledge (Table 1). Mean values for life satisfaction, spending habits, celebrity idolization, peer consultation, generosity, and materialism varied minimally-less than 0.43 in all cases-among boys, girls, 12-year-olds, 13-year-olds, and 14-year olds (Table 2). Thus, similar to prior findings, no statistically significant differences were found in levels of life satisfaction (Opshau, 2013), materialism (Workman \& Lee, 2011), and related measured factors when comparing males and females. This is particularly compelling when taking into account that the girls spent $221 \%$ longer on Instagram than boys. Perhaps the environments of puberty and middle school impact young female and male teens to produce many shared values regardless of time spent on social media. (More questions comparing the nature of Instagram usage for respondents would be needed to assess this hypothesis.) However, when analyzing differences between age groups, life satisfaction and materialism appear to both increase slightly with age. This result aligns with the research by Harris Interactive which found that older teens (13-18) "consistently scored higher" than younger teens (8-12) "when queried on materialistic attitudes" (Reuters, 2007), but experimental research is needed to determine if the causes are environmental or intrinsic. 


\section{Comparison of Attitudes Before and After the Celebrity-endorsed Instagram Advertising}

Average levels of materialism virtually did not change before viewing the images (2.395) and afterward (2.365) (Table 3 , Row 3,8). Therefore, the 14 celebrity-endorsed advertisements did not immediately influence the middle school students to more (or less) greatly value the importance of material possessions in their own lives. Although no studies that were found have tested this specific relationship, this outcome contrasts Opree's study which found that the more television advertising middle school children were exposed to, the more materialistic their survey responses were. It must be noted that Opree's study tracked the children over a span of two years (2012). Aside from this key difference, the relatively steady levels of materialism could also be related to the school's mission of developing students to be citizens with strong character and "self-knowledge;" which is actually conceptually consistent with the growing consensus that one's' surroundings, although typically through friends and family, influences the development of materialism as well (Flouri, 2004; Goldberg et al., 2003).

Life satisfaction also did not change a significant amount, averaging 3.275 before the images and 3.40 afterward, therefore signifying that the celebrity-endorsement ads did not have an immediate effect on the respondents' well-being either (Table 3, Row 9,10). This confirms the previous finding that the advertisements did not have a great impact on respondent's overall materialism, because decreased life satisfaction often correlates with higher levels of materialism (Ahuvia \& Wong, 2002; Belk, 1985; Burroughs \& Rindfleisch, 2002; Shrum et al., 2011; Sirgy et al., 2012). However, surveyees' average generosity decreased from $\$ 4$ before viewing the images to $\$ 3$ afterward (Table 3 , Row 6,7). This finding suggests generosity levels may fluctuate more independently of levels of materialistic values since respondents donated less to charity after viewing the celebrity-endorsed advertising notwithstanding more or less stagnant levels of materialism. In general, this is consistent with the results of Caughey's study which found that celebrities can influence fans' personal values and actions (Boon, 2001).

\section{Correlations}

The data led to the conclusion that the level of celebrity idolization was the most conclusive factor in determining the middle schooler's final level of materialism: celebrity idolization had a positive correlation with materialism both before and after viewing the images, with Pearson correlation coefficients (R) of 0.636 and 0.690 , respectively (Table 4). Thus, imitation of social media celebrities was a stronger predictor for materialism than socioeconomic status (measured through the average cost of living for each of the residents' cities), or any other factor listed in Table 3. This is consistent with the notion that the effectiveness of celebrity endorsement relies on the viewer's prior opinion of that celebrity (Knolles \& Matthes, 2016).

Additionally, there were 2 other slight positive correlations between (1) time on Instagram and materialism (before and after) $(\mathrm{R}=0.351$ and 0.358$)$ and (2) celebrity idolization and final generosity. There was virtually no correlation between any other relationship (Table 4). In light of all these correlations that do not exist, these three correlations that do exist reaffirm the analyses and conclusions from the discussion subsections above; of all factors, higher levels of celebrity idolization had the most consistent association with higher levels of materialism in the middle schoolers. And the more time spent on Instagram-and likely, the more exposure to this type of advertising-the more materialistic and less generous students were. 
Table 4: Correlations with $\mathrm{R}^{2}$ Values

\begin{tabular}{|c|c|c|c|c|c|c|c|c|}
\hline & $\begin{array}{c}\text { Life Sat- } \\
\text { isf. }\end{array}$ & $\begin{array}{c}\text { Spending } \\
\text { Habits }\end{array}$ & $\begin{array}{c}\text { Celeb. } \\
\text { Idoliza- } \\
\text { tion }\end{array}$ & IG time & $\begin{array}{l}\text { Generos- } \\
\text { ity before }\end{array}$ & $\begin{array}{l}\text { Generos- } \\
\text { ity after }\end{array}$ & $\begin{array}{c}\text { Material- } \\
\text { ism be- } \\
\text { fore }\end{array}$ & $\begin{array}{l}\text { Material- } \\
\text { ism after }\end{array}$ \\
\hline $\begin{array}{c}\text { Life Satis- } \\
\text { faction }\end{array}$ & $(\mathrm{n} / \mathrm{a})$ & 0.064 & 0.002 & 0.024 & 0.005 & 0.013 & 0.006 & 0.05 \\
\hline $\begin{array}{c}\text { Spending } \\
\text { Habits }\end{array}$ & 0.064 & $(\mathrm{n} / \mathrm{a})$ & 0.019 & 0.002 & 0.044 & 0.017 & 0 & 0 \\
\hline $\begin{array}{c}\text { Celebrity } \\
\text { Idoliza- } \\
\text { tion }\end{array}$ & 0.002 & 0.019 & $(\mathrm{n} / \mathrm{a})$ & 0.015 & 0.01 & 0.137 & 0.405 & 0.476 \\
\hline $\begin{array}{c}\text { Time on } \\
\text { IG }\end{array}$ & 0.024 & .002 & 0.015 & $(\mathrm{n} / \mathrm{a})$ & 0.011 & 0.121 & 0.123 & 0.128 \\
\hline $\begin{array}{l}\text { Generos- } \\
\text { ity before } \\
\text { images }\end{array}$ & 0.005 & 0.044 & 0.01 & 0.011 & $(\mathrm{n} / \mathrm{a})$ & $(\mathrm{n} / \mathrm{a})$ & 0.04 & 0.099 \\
\hline $\begin{array}{c}\text { Generos- } \\
\text { ity after } \\
\text { images }\end{array}$ & 0.013 & 0.017 & 0.137 & 0.121 & $(\mathrm{n} / \mathrm{a})$ & $(\mathrm{n} / \mathrm{a})$ & 0.171 & $(\mathrm{n} / \mathrm{a})$ \\
\hline $\begin{array}{c}\text { Material- } \\
\text { ism be- } \\
\text { fore im- } \\
\text { ages }\end{array}$ & 0.006 & 0 & 0.405 & 0.123 & 0.04 & 0.171 & $(\mathrm{n} / \mathrm{a})$ & 0.057 \\
\hline $\begin{array}{l}\text { Material- } \\
\text { ism after } \\
\text { images }\end{array}$ & 0.05 & 0 & 0.476 & 0.128 & 0.099 & 0.057 & $(\mathrm{n} / \mathrm{a})$ & $(\mathrm{n} / \mathrm{a})$ \\
\hline $\begin{array}{c}\text { Socio- } \\
\text { economic } \\
\text { status }\end{array}$ & 0.017 & 0.12 & 0.114 & 0.06 & 0.027 & 0.003 & 0.119 & 0.084 \\
\hline
\end{tabular}

\section{Limitations}

The first limitation of the study concerns the nature and size of the sample population. Since promised incentives do not alter data quality (Singer, 2012), participants were offered an optional cash reward within the survey. The cash reward was not advertised as a pre-survey incentive since a study on materialism could elicit biased responses if 
students were offered a material reward to participate. However, this decision may have led to a smaller sample population than ideal. The study was limited to one school, which consists largely of upper-middle-class families and is not representative of Southern California as a whole. Furthermore, since only 40 out of the $300+$ middle schoolers at the school took part in the survey, the results may not even be a representative sample of this specific middle school population either. For these reasons the findings certainly do not represent the entire Southern California middle school population.

Secondly, time restraints prevented the author from first surveying the middle school students to see what celebrities are the most relevant and popular among them in the first place, so results may be skewed depending on potential mismatch between media figures and respondents. If the study was conducted again, students would decide for themselves which celebrities they idolize the most, and the author would select photos from there. In retrospect, questions would not simply measure levels of celebrity idolization overall, but of the specific ones included in the study to more accurately access degrees of celebrity idolization.

The flexibility that participants had to take the surveys at their convenience allowed for some potential issues, if the students took the surveys together or shared their own responses with other participants before those students completed the surveys. In an improved study, participants would be instructed to refrain from sharing their responses and opinions of the survey since social desirability leads to fewer truthful responses (Bergen \& Labonté, 2019).

Finally, correlational studies do not prove causation. With the chosen method, it is not known whether materialism is caused by the idolization of celebrities in sponsored Instagram posts or vice versa, although research suggests that these values may reinforce each other (Pinsker, 2018). Future researchers should utilize longer-term experiments with control groups-one that is not shown advertising at all and one that is shown advertising without celebrity endorsement-to more confidently assess the relationship between materialism and celebrity-endorsed advertising in particular.

\section{Thematic Future Directions}

In addition to the ones already described, other future directions in research could include surveying a wider range of age groups to verify if average materialism levels are highest during middle school, as previous research suggests (Chaplin \& John, 2007; Reuters, 2007; Pinsker 2018), or if materialism is relatively uniform across age groups.

It would also be interesting for future studies to examine the impact of celebrity-endorsed advertising on other popular social networks on users' own Instagram accounts since research indicates interactive features such as commenting leads to even greater relatability to celebrities (Scmidt 2007).

Additionally, researchers may feel impelled to look into the finding that, on average, the female middle schoolers spent $221 \%$ longer on Instagram than their male counterparts. First, future studies should test if this genderimbalance phenomenon persists at other schools, on other social networking sites, and areas of the country. Then, studies could compare the intent behind and reward out of using Instagram for different genders to try to pinpoint why girls spend longer on social media than boys do.

\section{Conclusion}

Limitations aside, this study contributes valuable new insights into how celebrity-endorsed social media advertising impacts young adolescents. Namely, this research begins to fill both the demographic gap (young teens in 2020) and surface the thematic bridge (materialism and Instagram celebrity endorsement). Based on the argument of materialism as a negative outcome (Ahuvia \& Wong, 2002; Belk, 1985; Burroughs \& Rindfleisch, 2002; Shrum et al., 2011; Sirgy et al., 2012), this study continues to highlight the influences of such a maladaptive trait. As summarized, moderate levels of materialism in the sample of young teens corresponded with high levels of generosity and life satisfaction. As demonstrated, the degree to which young teens look up to Instagram celebrities may predict the extent to which 
celebrity-endorsed advertising increases materialism. Further, spending habits and socioeconomic status appear unrelated to materialism, generosity, and life satisfaction.

\section{Implications}

Media literacy education in schools could be beneficial in spreading awareness to middle schoolers, especially in light of the fact that-as both the survey data and prior research highlight-many social media users are underage (Influence Central, 2017) and in critical periods of identity development (Wolfe, 2016). Thus, the findings will be shared with the other members of the school's middle school wellness committee to facilitate discussion about these topics at the next meetings with the middle schoolers. Instructors of the middle school "life skills" classes will also be asked to consider talking about the importance of choosing positive celebrity role models and developing healthy consumption patterns. Most importantly, education should continue to stress the importance of intrinsic goals in fostering motivation for academic achievement and social engagement, as research supports the effectiveness of similar intervention (Knoll \& Matthes, 2016). Students feeling particularly detached from their values may consider scrutinizing their list of followed celebrities on social media. The discouragement of celebrity idolization is expected to decrease materialism.

\section{References}

Adobe Digital Insights. (2018). State Of Digital Advertising: Summit 2018. Adobe. Retrieved from https://wwwimages2.adobe.com/content/dam/acom/en/modal-offers/2018-adi-advertising/pdfs/state-of-digital-advertising-2018-FINAL.pdf.

Anderson, M., \& Jiang, J. (2018, November 30). Teens, Social Media \& Technology 2018. Pew Research Center. Retrieved from https://www.pewresearch.org/internet/2018/05/31/teens-social-media-technology-2018/.

Bamossy, G. (2003). Understanding Materialism Among Youth. Journal Of Consumer Psychology, 13(3), 278-288. Retrieved from https://www.academia.edu/3061350/Understanding Materialism Among Youth.

Bakırtaş, H., Buluş, C., \& Bakırtaş, İ. (2014). The Effects of Materialism and Consumer Ethics on Ecological Behavior: An Empirical Study. European Journal of Sustainable Development, 3(4) 125-134. Retrieved from https://pdfs.semanticscholar.org/fb32/92cd2e316c94a168e9b247a6ea2d74e48495.pdf.

Bauer, M., Wilkie , J., Kim, J., \& Bodenhausen, G. (2012). Cuing consumerism: Situational materialism undermines personal and social well-being. Institutional Knowledge at Singapore Management University. Retrieved from https://ink.library.smu.edu.sg $/ \mathrm{cgi} /$ viewcontent.cgi?article $=5945 \&=\&$ context $=1 \mathrm{kcsb}$ research \&sei-redir=1\&referer=https $\% 3 \mathrm{~A} \% 2 \mathrm{~F} \% 2 \mathrm{Fwww}$.google.com $\% 2 \mathrm{Furl} \% 3 \mathrm{Fq} \% 3 \mathrm{Dhttps} \% 3 \mathrm{~A} \% 2 \mathrm{~F} \% 2 \mathrm{Fink}$.library.smu.edu.sg\%2Fcgi\%2Fviewcontent.cgi\%3Farticle $\% 253 \mathrm{D} 5945 \% 2526$ context $\% 253 \mathrm{Dlkcsb}$ research\%26sa\%3DD\%26ust\%3D1575917015077000\%26usg\%3DAFQjCNG_pdio5TAp89bwfkPyPZlltMwRg\#search="https://ink.library.smu.edu.sg/cgi/viewcontent.cgi?article=5945\&context=lkcsb research".

Belk, R. (1984, January 1). Three Scales to Measure Constructs Related to Materialism: Reliability, Validity, and Relationships to Measures of Happiness. Advances in Consumer Research, 11, 291-297. Retrieved December 9, 2019, from http://acrwebsite.org/volumes/6260/volumes/v11/NA-11. 
Belk, R. (1985). Materialism: Trait Aspects of Living in the Material World. Journal of Consumer Research, 12(3), 265-280. Retrieved from www.jstor.org/stable/254373

Bergen, N., \& Labonté, R. (2019). "Everything Is Perfect, and We Have No Problems": Detecting and Limiting Social Desirability Bias in Qualitative Research. Qualitative Health Research, 30(5), 783-792.

doi:10.1177/1049732319889354

Bergkvist, L., \& Zhou, K. Q. (2016). Celebrity endorsements: a literature review and research agenda. International Journal of Advertising, 35(4), 642-663. doi: 10.1080/02650487.2015.1137537

Best, P., Manktelow, R., \& Taylor, B. (2014, March 11). Online communication, social media and adolescent wellbeing: A systematic narrative review. Retrieved from https:/www.sciencedirect.com/science/article/pii/S0190740914000693

Boon, S. (2001). Admirer-celebrity relationships among young adults. Explaining perceptions of celebrity influence on identity. Human Communication Research, 27(3), 432-465. doi: 10.1093/hcr/27.3.432

Bredemeier, H., \& Tony, J. (1960). Social Problems in America: Costs and Casualties in an Acquisitive Society. American Journal of Sociology, 66(2), 207. Retrieved from https://www.journals.uchicago.edu/doi/pdfplus/10.1086/222870.

Burke, K. (2017, June 19). Social Butterflies- How Social Media Influencers are the New Celebrity Endorsement. Retrieved from https://vtechworks.lib.vt.edu/handle/10919/78221

Caughey, J. L. (1994). Gina as Steven: The Social and Cultural Dimensions of a Media Relationship. Visual Anthropology Review, 10(1), 126-135. doi: 10.1525/var.1994.10.1.126

Chaplin, L., \& John, D. (2005). Materialism in Children and Adolescents: The Role of the Developing Self-Concept. Advances in Consumer Research, 32(1), 219. Retrieved from http://search.ebscohost.com/login.aspx?di$\underline{\text { rect }=\text { true } \& d b=a q h \& A N=83386568}$

Chaplin, L., \& John, D. (2007). Growing up in a Material World: Age Differences in Materialism in Children and Adolescents. Journal Of Consumer Research, 34. Retrieved from http://assets.csom.umn.edu/assets/93681.pdf.

Chaplin, L. N., John, D. R., Rindfleisch, A., \& Froh, J. J. (2018). The impact of gratitude on adolescent materialism and generosity. The Journal of Positive Psychology, 14(4), 502-511. doi:10.1080/17439760.2018.1497688

Chapple, C., \& Cownie, F. (2017). An investigation into viewers' trust in and response towards disclosed paid-forendorsements by YouTube Lifestyle vloggers. Journal of Promotional Communications. Retrieved from https://scholar.google.com/scholar lookup?hl=en\&publication year=2017\&pages=110-36\&author=C.

Chapple\&author=F. Cownie\&title=An investigation into viewers' trust in and response towards disclosed paid-forendorsements by YouTube lifestyle vloggers

Creswell, J. (2008, June 22). Nothing Sells Like Celebrity. The New York Times. Retrieved from https://www.ny$\underline{\text { times.com/2008/06/22/business/media/22celeb.html?mtrref=www.google.com\&assetType=REGIWALL. }}$ 
Curalate, Inc. (2017, November). Curalate Consumer Survey: Social Content is the New Storefront. Curalate. Retrieved from http://pages.curalate.com/rs/496-DAU-231/images/Curalate Consumer-Survey Nov17 V4.pdf.

Curtin, S. (2019, October). Death Rates Due to Suicide and Homicide Among Persons Aged 10-24: United States, 2000-2017. Retrieved from https://www.cdc.gov/nchs/data/databriefs/db352-h.pdf

Diener, E. (2010). The Satisfaction With Life Scale. Retrieved from https://www.tandfonline.com/doi/abs/10.1207/s15327752jpa4901 13

Dittmar, H., Bond, R., Hurst, M., \& Kasser, T. (2014). The relationship between materialism and personal well-being: A meta-analysis. Journal of Personality and Social Psychology, 107(5), 879-924. Retrieved from https://psycnet.apa.org/record/2014-44347-005.

Elberse, A., \& Verleun, J. (2011). The Economic Value of Celebrity Endorsements. Journal of Advertising Research. Retrieved from https://pdfs.semanticscholar.org/81f3/6bcf4d254b53363ae9a80445b2dfd2e6af36.pdf.

Emarketer. (2019, February 1). US Facebook and Instagram Net Ad Revenues, 2016-2021 (billions). Emarketer. Retrieved from https://www.emarketer.com/chart/229346/us-facebook-instagram-net-ad-revenues-2016-2021-billions.

Fincham, J. E. (2008). Response Rates and Responsiveness for Surveys, Standards, and the Journal. American Journal of Pharmaceutical Education, 72(2), 43. doi:10.5688/aj720243

Geiger, A., \& Davis, L. (2019, July 12). A growing number of American teenagers - particularly girls - are facing depression. Retrieved from https://www.pewresearch.org/fact-tank/2019/07/12/a-growing-number-of-americanteenagers-particularly-girls-are-facing-depression/

Gesenhues, A. (2019, July 29). Has Instagram increased its ad load? Marketers report as many as 1 in 4 posts are ads. Marketing Land. Retrieved from https://marketingland.com/has-instagram-increased-its-ad-load-marketers-report-as-many-as-1-in-4-posts-are-ads-264109.

Hoffman1, S. J., Mansoor1, Y., Belluz6, J., Caulfield7, T., Freedhoff8, Y., Lavis2, J. N., \& Sharma11, A. M. (2017, January 21). Celebrities' impact on health-related knowledge, attitudes, behaviors, and status outcomes: protocol for a systematic review, meta-analysis, and meta-regression analysis. Systematic Reviews, 6(13).Retrieved from https://systematicreviewsjournal.biomedcentral.com/articles/10.1186/s13643-016-0395-1.

Influence Central. (2017). Kids \& Tech: The Evolution of Today's Digital Natives. Influence Central. Retrieved from http://influence-central.com/kids-tech-the-evolution-of-todays-digital-natives/.

InfluencerDB. (2018). Instagram influencer marketing spending worldwide from 2013 to 2020 (in million U.S. dollars) [Graph]. In Statista. Retrieved from https://www.statista.com/statistics/950920/global-instagram-influencermarketing-spending/

Instagram. (2017, September 25). 2M Monthly Advertisers on Instagram. Instagram. Retrieved from https://business.instagram.com/blog/welcoming-two-million-advertisers. 
Kasser, T., \& Ryan, R. (1993). A dark side of the American dream: Correlates of financial success as a central life aspiration. Journal of Personality and Social Psychology, 65(2), 410-422. Retrieved from https://psycnet.apa.org/record/1993-45246-001.

Kasser, T. (2014, December 16). What Psychology Says About Materialism and the Holidays. American Psychological Association. Retrieved from https://www.apa.org/news/press/releases/2014/12/materialism-holidays.

Kasser, T., Ryan, R. M., Couchman, C. E., \& Sheldon, K. M. (n.d.). Materialistic values: Their causes and consequences. Psychology and Consumer Culture: The Struggle for a Good Life in a Materialistic World., 11-28. doi:10.1037/10658-002

Katsingris, P. (2019). Nielsen Total Audience Report. Retrieved from https://www.nielsen.com/wp-content/uploads/sites/3/2019/04/q3-2018-total-audience-report.pdf

Keng, K. (2000, March). The Influence of Materialistic Inclination on Values, Life ... Retrieved April 24, 2020, from https://link.springer.com/article/10.1023/A:1006956602509

Knoll, J., \& Matthes, J. (2016). The effectiveness of celebrity endorsements: A meta-analysis. Journal of the Academy of Marketing Science, 45(1), 55-75. doi:10.1007/s11747-016-0503-8

Lafferty, B. A., \& Goldsmith, R. E. (1999). Corporate Credibility's Role in Consumers' Attitudes and Purchase Intentions When a High versus a Low Credibility Endorser Is Used in the Ad. Journal of Business Research, 44(2), 109-116. doi: 10.1016/s0148-2963(98)00002-2

Lee, J., \& Shrum, L. (2012). Conspicuous Consumption versus Charitable Behavior in Response to Social Exclusion: A Differential Needs Explanation. Journal of Consumer Research,39(3), 530-544. doi:10.1086/664039

Linqia, Inc. . (2016). The State of Influencer Marketing 2017. Linqia. Retrieved from http://www.linqia.com/wpcontent/uploads/2016/11/The-State-of-Influencer-Marketing-2017 Final-Report.pdf.

Lipovčan, L., Prizmić-Larsen, Z., \& Brkljačić, T. (2015, November 14). Materialism, affective states, and life satisfaction: Case of Croatia. Retrieved April 20, 2020, from https://www.ncbi.nlm.nih.gov/pmc/articles/PMC4644134/

Martin, C. A., \& Bush, A. J. (2000). Do role models influence teenagers' purchase intentions and behavior? Journal of Consumer Marketing, 17(5), 441-453. doi: 10.1108/07363760010341081

Martin, F., Wang, C., Petty, T., Wang, W., \& Wilkins, P. (2018). Middle School Students' Social Media Use. Journal of Educational Technology \& Society, 21(1), 213-224. Retrieved from www.jstor.org/stable/26273881

Maxwell, J. (2017). 10 retailer investments for an uncertain future. PricewaterhouseCoopers. Retrieved from https://www.pwc.com/gx/en/industries/assets/total-retail-2017.pdf.

Miller, P. (n.d.). Tipsheet - Nonresponse Error. Retrieved April 20, 2020, from https://dism.ssri.duke.edu/surveyhelp/tipsheets/tipsheet-nonresponse-error

Moschis, G. P., \& Moore, R. L. (1982). A Longitudinal Study of Television Advertising Effects. Journal of Consumer Research, 9(3), 279. doi:10.1086/208923 
Muncy, J., \& Eastman, J. (1998). Materialism and Consumer Ethics: An Exploratory Study. Journal of Business Ethics, 17(2), 137-145. Retrieved from www.jstor.org/stable/25073064

Murdoch, M., Simon, A. B., Polusny, M. A., Bangerter, A. K., Grill, J. P., Noorbaloochi, S., \& Partin, M. R. (2014). Impact of different privacy conditions and incentives on survey response rate, participant representativeness, and disclosure of sensitive information: A randomized controlled trial. BMC Medical Research Methodology, 14(1). doi:10.1186/1471-2288-14-90

Neighmond, P. (2019, March 14). A Rise In Depression Among Teens And Young Adults Could Be Linked To Social Media Use. Retrieved from https://www.npr.org/sections/health-shots/2019/03/14/703170892/a-rise-in-depression-among-teens-and-young-adults-could-be-linked-to-social-medi

North, A., Sheridan, L., Maltby, J., \& Gillett, R. (2007, December). Attributional Style, Self-Esteem, and Celebrity Worship. Journal of Media Psychology, 9(2), 291-308. Retrieved from https://www.tandfonline.com/doi/abs/10.1080/15213260701285975?scroll=top\&needAccess=true \&journalCode $=$ hmep20.

Nouri, M. (2018, September 12). The Power of Influence: Traditional Celebrity vs Social Media Influencer. Retrieved from https://scholarcommons.scu.edu/cgi/viewcontent.cgi?article=1032\&context=engl_176.

O'Guinn, T., \& Shrum, L. (1997). The Role of Television in the Construction of Consumer Reality. Journal of Consumer Research, 23(4), 278-294. Retrieved from www.jstor.org/stable/2489565

O'Keeffe, G., \& Clarke-Pearson, K. (2011, April 01). The Impact of Social Media on Children, Adolescents, and Families. Retrieved from https://pediatrics.aappublications.org/content/127/4/800?source=post page----$\underline{3 \mathrm{f} 89 \mathrm{a} 46 \mathrm{ab} 400}$

Oladipo, S. E., Adenaike, F. A., Adejumo, A. O., \& Ojewumi, K. O. (2013). Psychological Predictors of Life Satisfaction among Undergraduates. Procedia - Social and Behavioral Sciences, 82, 292-297. doi:10.1016/j.sbspro.2013.06.263

Opree, S., Buijzen, M., \& Valkenburg, P. (2012). Lower Life Satisfaction Related to Materialism in Children Frequently Exposed to Advertising. American Academy of Pediatrics. doi: 10.1542/peds.2011-3148

Opree, S., Reijmersdal, E., Buijzen, M., \& Valkenburg, P. (2013). Children's Advertising Exposure, Advertised Product Desire, and Materialism: A Longitudinal Study. Communication Research. doi:

$10.1177 / 0093650213479129$

Oxford English Dictionary (2016). Accessed Dec 9, 2019. Oxford English Dictionary. Retrieved from www.oed.com

Phua, J., Jin, S. V., \& Hahm, J. M. (2017). Celebrity-endorsed e-cigarette brand Instagram advertisements: Effects on young adults' attitudes towards e-cigarettes and smoking intentions. Journal of Health Psychology, 23(4), 550560. doi: $10.1177 / 1359105317693912$

Pinsker, J. (2018, September 5). Why Kids Want Things. The Atlantic. Retrieved from https://www.theatlantic.com/family/archive/2018/08/kids-materialism/568987/. 
Porter, S. (2004). Multiple Surveys of Students and Survey Fatigue. Retrieved from https://oia.unm.edu/surveys/survey-fatigue.pdf

Reuters. (2007, January 16). Teenagers do grow more materialistic: study. Reuters. Retrieved from https://www.reuters.com/article/us-life-materialism/teenagers-do-grow-more-materialistic-study-idUSN1620879220070116.

Richins, M. (1987). Media, Materialism, and Human Happiness. Advances in Consumer Research, 14.

Richins, M. L., \& Dawson, S. (1992, February). A Consumer Values Orientation for Materialism and Its Measurement. Journal of Consumer Research, 19(3), 303-316. doi: 10.1086/209304.

Richins, M. L. (2017, August 3). Materialism pathways: The processes that create and perpetuate materialism. Journal of Consumer Psychology, 27(4), 480-499. Retrieved from https://www.sciencedirect.com/science/article/abs/pii/S1057740817300517.

Rideout, V. (2018). Social Media, Social Life: Teens Reveal Their Experiences. Retrieved from https://www.commonsensemedia.org/sites/default/files/uploads/research/2018 cs socialmediasociallife executivesummary-finalrelease 3 lowres.pdf

Rucker, D., \& Galinskey, A. (2009, May). Conspicuous consumption versus utilitarian ideals: How different levels of power shape consumer behavior. Journal of Experimental Social Psychology, 45(3), 549-555. doi:

10.1016/j.jesp.2009.01.005

Sansone, R. A., \& Sansone, L. A. (2014, January). "I'm Your Number One Fan"- A Clinical Look at Celebrity Worship. Innovations in Clinical Neuroscience, 11(1-2), 39-43. Retrieved from https://www.ncbi.nlm.nih.gov/pmc/articles/PMC3960781/.

Saunders, S. (2001). Fromms Marketing Character And Rokeach Values. Social Behavior and Personality: an International Journal, 29(2), 191-195. doi: 10.2224/sbp.2001.29.2.191

Schmidt, J. (2007). Blogging Practices: An Analytical Framework. Journal of Computer-Mediated Communication, 12(4), 1409-1427. doi: 10.1111/j.1083-6101.2007.00379.x

Schouten, A. P., Janssen, L., \& Verspaget, M. (2019). Celebrity vs. Influencer endorsements in advertising: the role of identification, credibility, and Product-Endorser fit. International Journal of Advertising, 1-24. doi:

$10.1080 / 02650487.2019 .1634898$

Schultze, Q., Anker, R., Bratt, J., Romanowkski, W., Worst, J., \& Zuidervaart, L. (1991). Dancing in the Dark: Youth, Popular, Culture, and the Electronic Media.

Schwab, K. (2016, January). The Fourth Industrial Revolution: What it means and how to respond. Retrieved from https://www.weforum.org/agenda/2016/01/the-fourth-industrial-revolution-what-it-means-and-how-to-respond/

Shrum, L. J., Borroughs, J. E., Lee, J., \& Rindfleisch, A. (2011). An Online Process Model of Second-Order Cultivation Effects: How Television Cultivates Materialism and Its Consequences for Life Satisfaction. Human Communication Research, 37, 34- 57. doi: 10.1111/j.1468-2958.2010.01392.x 
Singer, E. (2012, October). The Use and Effects of Incentives in Surveys [PDF]. Palo Alto: Stanford University.

Sirgy, M., Gurel-Atay, E., Webb, D., Cicic, M., Husic, M., Ekici, A., . . Johar, J. (2012). Linking Advertising, Materialism, and Life Satisfaction. Social Indicators Research, 107(1), 79-101. Retrieved from www.jstor.org/stable/41427023

Sirgy, M., Gurel-Atay, E., Webb, D., Cicic, M., Husic-Mehmedovic, M., Ekici, A., . . Johar, J. (2013). Is Materialism All That Bad? Effects on Satisfaction with Material Life, Life Satisfaction, and Economic Motivation. Social Indicators Research, 110(1), 349-366. Retrieved from www.jstor.org/stable/24718708

Srivastava, A., Locke, E. A., \& Bartol, K. M. (2001). Money and subjective well-being: It's not the money, it's the motives. Journal of Personality and Social Psychology, 80(6), 959-971. Retrieved from https://psycnet.apa.org/record/2001-06600-009.

Steinfield, L. (2016). Rethinking materialism: a question of judgements and enactments of power (PhD thesis). University of Oxford.

Tiller, J. (2011, May 5). Why Teenagers Obsess Over Pop Stars. Child Mind Institute. Retrieved from https://childmind.org/blog/teenagers-obsess-pop-stars/.

Tsang, J., Carpenter, T. P., Roberts, J. A., Frisch, M. B., \& Carlisle, R. D. (2014). Why are materialists less happy? The role of gratitude and need satisfaction in the relationship between materialism and life satisfaction. Personality and Individual Differences, 64, 62-66. doi:10.1016/j.paid.2014.02.009

Van Bowen, L., \& Gilovich, T. (2004, January). To Do or to Have? That Is the Question. Journal of Personality and Social Psychology, 85(6), 1193-202. doi: 10.1037/0022-3514.85.6.1193

Weinstein, E. (2018, February 21). The social media see-saw: Positive and negative influences on adolescents' affective well-being - Emily Weinstein, 2018. Retrieved from https://journals.sagepub.com/doi/abs/10.1177/1461444818755634

Winter, D. (2004). Shopping for sustainability: Psychological solutions to overconsumption. American Psychological Association. Retrieved from https://psycnet.apa.org/record/2003-88094-005.

Wolfe, N. (2016). Adolescent Identity Formation and the Singing Voice. The Choral Journal, 57(3), 49-52. Retrieved from www.jstor.org/stable/24883875

Wong, N., \& Ahuvia, A. (2002, October). Personality and Values Based Materialism: Their Relationship and Origins. Journal of Consumer Psychology, 12(4), 389-402. doi: 10.1207/S15327663JCP1204_10

Wu, P. (1998, January 01). Goal structures of materialists vs. non-materialists: The effects of TV exposure on materialism and the relationship between materialism and happiness. Retrieved from https://deepblue.lib.umich.edu/handle/2027.42/131134

Yamaguchi, M., \& Halberstadt, J. (2012). Goals and well-being in New Zealand. New Zealand Journal of Psychology, 41(2), 7-12. Retrieved from https://www.psychology.org.nz/wp-content/uploads/Halberstadt.pdf. 
Yue, X. D., \& Cheung, C.-K. (2000). Selection of favourite idols and models among Chinese young people: A comparative study in Hong Kong and Nanjing. International Journal of Behavioral Development, 24(1), 91-98. doi: $10.1080 / 016502500383511$

Zenith Media. (2019, October 28). Social media overtakes print to become the third-largest advertising channel.

Zenith. Retrieved from https://www.zenithmedia.com/social-media-overtakes-print-to-become-the-third-largest-advertising-channel/. 